\title{
Hamlet em Moscou: notas para uma breve alocução aos atores do Teatro de Arte de Moscou*
}

\author{
Gordon Craig
}

\section{9 de novembro de 1909}

ão quero que vocês, quando chegarem a representar este Drama de Reis e Príncipes, criem a impressão de serem atores atuando, pois isto quase sempre significa algo insincero e, por alguma razão vergonhosa, temos sido forçados a vê-lo denominado de "teatral".

Mas, vocês não devem ir para o outro extremo. Se o fizerem, criarão uma impressão de pessoas comuns que nunca viram uma corte, muito menos um rei, e que não têm nenhuma idéia da Realeza.

O Real ainda não é o Teatral, embora às vezes os dois sejam confundidos. Vocês devem tentar mover-se e falar como se estivessem em uma atmosfera que é invulgar... pois Shakespeare fê-la invulgar.

Para consegui-lo devem tentar pensar de maneira invulgar e olhar todas as coisas como coisas invulgares. $\mathrm{O}$ palco não oferece nada mais difícil para os talentos de vocês.

Sou de opinião que nenhum grupo de atores logrará representar cabalmente este senso de Realeza até que eles se tornem eles mesmos Reais... e para fazê-lo será necessário que vivam suas vidas tendo por objeto supremo a cultura, pois somente por este meio poderão absorver aquele ar que, depois de penetrar em um homem, empresta-lhe ao menos uma certa maneira que é magnificente e um certo tom que é doce.

É esta maneira e este tom que necessitamos para a representação dos Poemas Dramáticos de Shakespeare.

Eu disse cultura, pois propositalmente limito nossas aspirações aqui à cultura: se eu fosse adiante, deveria dizer que temos de entrar primeiro naquele estado espiritual de êxtase que podemos melhor imaginar do que falar a respeito. Mas para o nosso propósito... o propósito de Shakespeare... um estado Real é suficiente... ou antes, não é nem a metade do caminho para um estado religioso; e se pudermos alcançálo de um modo ou de outro, não seremos todos muito afortunados, chegando um passo mais perto em direção ao estado espiritual?

E como alcançá-lo?

Agora, aqui, vocês me colocam face a face com um Enigma ao mesmo tempo muito difícil e bastante fácil de resolver.

Como fazer algo que é Redondo em cada ponta ficar de pé tanto em uma, quanto na outra ponta... O Ovo de Colombo.

Posso ajudá-los mas não ensiná-los, pois isto é uma coisa que ninguém pode ensinar. Posso contar-lhes algumas coisas que, se acreditarem nelas, hão de colocá-los infalivelmente,

Gordon Craig (1872-1966). Encenador e teórico inglês.

* Texto originalmente publicado em The Mask, v. 7, n. 1, julho de 1914. Tradução de J. Guinsburg e Fany Kon. 
com o tempo, mais perto do estado que denominamos de extático.

Lembrem-se que o acme do êxtase não é a excitação aparente, porém a aparente calma. É o branco ardor da emoção... quer dizer, é quase transe. Esse estado tem mil nomes e assume uma miríade de formas. Nós o denominamos sabedoria.

É pura emoção, com todas as suas impurezas consumidas pelo fogo.

A fim de ter a coragem de empreender a tentativa de entrar em tal estado, alguma grande promessa deve-lhes ser feita de que a tentativa não será efetuada em vão.

Eu lhes faço essa promessa. Vocês precisam crer em mim, pois o que lhes digo é verdadeiro. Prometo-lhes que poderão alcançar qualquer estado desde que possam ver além dele. Sei muito bem que, pelo menos dez ou vinte vezes em suas vidas, vocês viram ou sentiram coisas que lhes pareceram loucura. Vocês evitaram esses sentimentos, não porque não gostassem deles, mas porque não viram utilidade alguma em apresentá-los... e assim ficaram com medo. Em outras palavras, a imaginação despertou em vocês e os possuiu por um ou dois momentos.

Agora, eu lhes digo que vocês precisam despertar a Imaginação e deixá-la possuí-los por inteiro. Tenham menos medo desses momentos quando eles chegarem. Vão em direção deles... corram o risco: sintam-se livres com eles; deixem que eles os possuam. O êxtase nada mais é senão um tipo de loucura... um tipo de loucura, lembrem-se, não qualquer tipo de loucura.

É tudo que é Rápido... Branco... Candente... Circular... Vasto... Firme.

É tudo o que vocês ousam sonhar e temem chegar perto.

É o grande Perigo.

E por esta razão mesma eu lhes digo que vocês devem ir ao seu encontro.

\section{0 de novembro de 1909}

Vocês querem chegar a entender e interpretar uma das maiores obras de gênio que o mundo possui e, portanto, precisam aproximar-se do estado desse gênio. Vocês precisam tornar-se extáticos. Vocês precisam soltar-se.

É impossível acreditar que possam interpretar uma obra tão grandiosa sem fazer uso de sua própria grandeza. Vocês não podem fazê-lo pela razão de cada um, que é a sua pequeneza. Vocês só podem fazê-lo pelo poder da Imaginação.

Se vocês puderem afrouxar os laços que aprisionam a liberdade de cada um (e sua imaginação é sua liberdade), vocês se encontrarão em condição para receber as comunicações de minha imaginação.

Poderemos então nos lançar ao trabalho e assenhorear-nos de seus segredos.

Se vocês permanecerem atados pelo intelecto ou pela razão, nunca hão de me entender, e seremos incapazes de chegar a algo. E eu tenho uma só coisa a lhes comunicar. O êxtase de Shakespeare.

Sob este cabeçalho um milhão de momentos de loucura estão reunidos.

\section{2 de Novembro de 1909}

A loucura é algo que, quando parece ter êxito, é chamada Heróica: quando falha é chamada Desatino.

Tentar o que é chamado o Impossível... isto é Loucura, e isto é Bem.

Em 20 de outubro de 480 a. C. travou-se a Batalha de Salamina. Os gregos tinham 380 navios, e os persas 2000, comandados por Xerxes. Eis a essência das palavras proferidas por Temístocles, o general grego, antes da batalha:

"O argumento disto era que, em todas as coisas que são possíveis à natureza e à situação dos homens, há sempre o mais alto e o mais baixo", e que eles precisam pretender o mais alto (Heródoto).

Eles assim o fizeram... e ganharam a batalha, e a loucura da tentativa foi chamada de Heróica... e justificada.

Vocês precisam fazer esta mesma tentativa louca em Hamlet; e "se as Musas nos abandonarem poderemos morrer” (Eurípides). 
E agora que já lhes disse o que eu quero de vocês, permitam-me adverti-los do que não fazer. Eu lhes imploro, não pensem muito.

Todo mundo tem o hábito de pensar, mas os atores modernos pensam muito, demais.

Pessoa nenhuma pode ver o céu pelo pensamento. Ela o vê e o concebe por meio dos sentidos.

Pensar quando a música é tocada seria ocioso... a gente deve simplesmente recebê-la na alma, através dos sentidos.

E assim deve ser com Hamlet. Deixem seus cérebros descansar e absorvam a beleza de Hamlet através dos olhos e dos ouvidos e não esqueçam o que é chamado toque, pois tem muito a ver com os movimentos de vocês.

Por meio do cérebro... penando, a gente pode atuar inteligentemente. Um homem inteligente é aquele que pensa... e vocês são conhecidos na Europa por serem a companhia de atores mais inteligente do Ocidente. Por meio dos sentidos e da alma vocês podem se tornar a mais profunda... a mais bela... a mais espiritual.

Assim, meus caros, não pensem muito... e sintam mais... muito mais. E deixem-me contar-lhes agora que eu aprecio muito todos vocês e farei qualquer coisa que estiver ao meu alcance, e tudo o que eu puder, para lhes ajudar durante esta sua interpretação do nosso Hamlet; mas são vocês que têm a tarefa mais árdua... que é induzir de bom grado a vocês mesmos ao mais simples estado de ser possível; e vocês só podem fazer isto escolhendo os meios mais elevados em lugar dos mais baixos: os sentidos e a alma em vez do cérebro.

\section{0 de novembro de 1909}

Foi provado por experiência que os Poemas Dramáticos Shakespearianos não podem ser representados da mesma maneira como representamos as peças modernas.

Toda a cor abandona os Poemas quando os interpretamos como interpretamos Ibsen, ou Tchékov.

Uma diferença entre Shakespeare e os escritores modernos é que, enquanto estes lidam com homens e mulheres, ele lida com tipos. Seu amante é o tipo de todos os amantes, que nada distingue salvo a sua paixão. Conhecemos detalhes acerca de sua vida, mas não conhecemos seu caráter. Shakespeare apenas nos mostra sua paixão. É a paixão do Poeta. Romeu canta e flutua diante de nós,... ele não conversa e anda. Ele ama... ama de novo... adoece... revive... adoece novamente... encontra o Destino... e morre.

E a Paixão, não o Caráter, cunha sua marca na tragédia toda de Romeu e Julieta. Somente lá onde algo de cômico deve ser revelado é que o Caráter é utilizado. Aprendi isto de meu amigo Yeats, nosso grande poeta irlandês.

Bem, então...

Uma companhia de atores que for representar esta peça deve pesar tudo isso cuidadosamente.

É porque os modernos produtores teatrais e atores tentam transformar os Poemas Dramáticos Shakespearianos em Peças de caracteres que os diretores de cena e atores atuais produzem resultados tão lamentáveis.

Hamlet é feito de Paixão... Estilo... Música... e Visão: mas não Caráter.

O Caráter aparece apenas incidentalmente nas figuras dos dois coveiros, e até eles têm algo daquela estranha aparência mística, aquela estranha e mágica expressão de rosto que detém nossa atenção em muitos dos retratos gregos e nos afrescos de Pompéia.

Olhando-os, ficamos surpresos com o que eles parecem ver... ou o que viram há muito tempo passado e está refletido em seus olhos e nas suas bocas. Uma gravidade que presta uma rara beleza aos olhos arregalados e à boca levemente aberta (nas máscaras da tragédia ou da comédia grega a boca era assim indicada, aberta. É o estado apaixonado. A boca fechada é o estado intelectual). O Caráter aparece também em Osric... e em Polônio.

E agora... como deve lidar com Hamlet uma companhia cujos atores treinaram para representar Peças de Caráter, como vocês fizeram, baseando seus métodos de representação na realidade em vez da Poesia e Imaginação? 
Devem eles fazer melhor do que tratar isto como um Romance... uma coisa de fantasia... ou uma realidade? Ousam eles a enfrentar a coisa como ela é?

Para mim, o segredo do poder de representar a peça reside na capacidade do ator entender a Paixão... o branco ardor da Paixão, a calma da Paixão, seu êxtase, e em ter dado a vida para a criação de uma técnica que deve transmitir êxtase àqueles que a estão olhando.

Fosse Grasso, nosso formidável Giovanni, interpretar Hamlet, deveríamos esperar e exigir ardor e rubor. Isto é uma outra história.

Hamlet é um santo... no entanto ama Ofélia... nisto ele é um santo; no entanto mata Polônio... nisto um santo...

Como assim?, perguntam vocês. Porque ele é a criação da Imaginação, porque um Poeta o criou. Ele não é realidade. Lembrem-se do sorriso da Gioconda que é o sorriso de Leonardo... Hamlet tem este sorriso.

No entanto Hamlet fala muito?

Bem, não devemos tocar nesse assunto terrível, pois ele é, infelizmente, demasiado verdadeiro. Pode o ator hoje em dia compreender este estado de ser, criado pela Imaginação?... Pode ele chegar a isto?

Vamos ao ponto, então. Esta é uma questão que lenta e relutantemente impele-nos para frente, em busca de uma resposta...

É tão Trágico como a Tragédia de Hamlet.

Se a resposta foi "Não", por que então não pode ele entendê-la?

Porque...

NÂO! Nenhum homem, mas somente anjos podem responder essa questão.

Quando o Amor, por sorte, retornar ao Teatro dos Teatros, ele renascerá. Quando ele voltar à Terra entrará no Teatro.

Venha, Chuang Tzu, venha me ajudar; diga-lhes o que quero dizer... ou melhor, digalhes que não estou totalmente errado no fato de, por Paixão, eu me referir não às paixões...

"Hui Tzu disse a Chuang Tzu: 'Existem, então, homens que não têm paixões'?
Chuang Tzu replicou: 'Certamente'!

'Mas se um homem não tem paixões', argumentou Hui Tzu, 'o que o torna homem?'

'Tao', replicou Chuang Tzu, 'dá-lhe sua expressão, e Deus dá-lhe sua forma. Como poderia ele não ser um homem?'

'Se, então, ele é um homem', disse Hui Tzu, 'como pode ele não ter paixões?'

'O que você entende por paixões', respondeu Chuang Tzu, 'não é o que eu entendo. Por um homem sem paixóes entendo um homem que não permite que o bem e o mal lhe perturbem a sua economia interna, mas, antes, conforma-se com o que quer que possa lhe suceder, como um fato natural, e não aumenta a soma de sua mortalidade.'

'Os homens puros dos velhos tempos dormiam sem sonhos, e acordavam sem ansiedade. Comiam sem discriminação, respirando haustos profundos. Pois homens puros tiram alento de suas profundezas mais extremas; os vulgares somente de suas gargantas. Dos desonestos, as palavras são arrotadas como vômito. Se as paixões dos homens são profundas, sua divindade é superficial.'

'Os homens puros dos velhos tempos não sabiam o que era amar a vida nem odiar a morte. Eles não exultavam o nascimento, nem se esforçavam em protelar a dissolução. Rápido vinham e rápido iam... nada mais. Não se esqueciam de onde foi que haviam brotado, nem procuravam apressar seu retorno para lá. Alegremente, representavam as partes a eles destinadas, esperando pacientemente pelo fim. Isto é o que se chama não levar o coração a perder-se de Tao, nem deixar o humano suplementar o divino. E isto é o que se entende por um homem puro'."

Eis a essência do que eu desejava dizer aos atores do Teatro de Arte de Moscou. Mas vendo seus bondosos semblantes e testas vincadas não tive coragem de acrescentar um vinco a mais. Tive ao menos o espírito para me abster uma vez mais... e eu fiz mais um desenho para um Über-Marionette. 